\title{
Pollutant-Removing Biofilter Strains Associated with High Ammonia and Hydrogen Sulfide Removal Rate in a Livestock Wastewater Treatment Facility
}

\author{
Dong-Hyun Kim ${ }^{1,+}{ }^{\text {, Hyun-Sik Yun }}{ }^{2,+}$, Young-Saeng Kim ${ }^{3, *}$ (D) and Jong-Guk Kim ${ }^{1,4, *}$ \\ 1 School of Applied Biosciences, Kyungpook National University, Daegu, 37224, Korea; kgwkk1@naver.com \\ 2 Department of Biology, College of Natural Sciences, Kyungpook National University, Daegu 41566, Korea; \\ yoon92623@naver.com \\ 3 Research Institute of Ulleung-do \& Dok-do, Kyungpook National University, Daegu 41566, Korea \\ 4 School of Life Sciences, BK21 FOUR KNU Creative BioResearch Group, Kyungpook National University, \\ Daegu 41566, Korea \\ * Correspondence: kyslhh1228@hanmail.net (Y.-S.K.); kimjg@knu.ac.kr (J.-G.K.) \\ + These authors contributed equally to this work.
}

check for

updates

Citation: Kim, D.-H.; Yun, H.-S.;

Kim, Y.-S.; Kim, J.-G.

Pollutant-Removing Biofilter Strains

Associated with High Ammonia and Hydrogen Sulfide Removal Rate in a Livestock Wastewater Treatment Facility. Sustainability 2021, 13, 7358. https://doi.org/10.3390/su13137358

Academic Editor: José

Alberto Herrera-Melián

Received: 23 April 2021

Accepted: 25 June 2021

Published: 30 June 2021

Publisher's Note: MDPI stays neutral with regard to jurisdictional claims in published maps and institutional affiliations.

Copyright: (c) 2021 by the authors. Licensee MDPI, Basel, Switzerland. This article is an open access article distributed under the terms and conditions of the Creative Commons Attribution (CC BY) license (https:/ / creativecommons.org/licenses/by/ $4.0 /)$.

\begin{abstract}
This study analyzed the microbial community metagenomically to determine the cause of the functionality of a livestock wastewater treatment facility that can effectively remove pollutants, such as ammonia and hydrogen sulfide. Illumina MiSeq sequencing was used in analyzing the composition and structure of the microbial community, and the 16S rRNA gene was used. Through Illumina MiSeq sequencing, information such as diversity indicators as well as the composition and structure of microbial communities present in the livestock wastewater treatment facility were obtained, and differences between microbial communities present in the investigated samples were compared. The number of reads, operational taxonomic units, and species richness were lower in influent sample (NLF), where the wastewater enters, than in effluent sample (NL), in which treated wastewater is found. This difference was greater in June 2019 than in January 2020, and the removal rates of ammonia (86.93\%) and hydrogen sulfide (99.72\%) were also higher in June 2019. In both areas, the community composition was similar in January 2020, whereas the influent sample (NLF) and effluent sample (NL) areas in June 2019 were dominated by Proteobacteria (76.23\%) and Firmicutes (67.13\%), respectively. Oleiphilaceae (40.89\%) and Thioalkalibacteraceae $(12.91 \%)$, which are related to ammonia and hydrogen sulfide removal, respectively, were identified in influent sample (NLF) in June 2019. They were more abundant in June 2019 than in January 2020. Therefore, the functionality of the livestock wastewater treatment facility was affected by characteristics, including the composition of the microbial community. Compared to Illumina MiSeq sequencing, fewer species were isolated and identified in both areas using culture-based methods, suggesting Illumina MiSeq sequencing as a powerful tool to determine the relevance of microbial communities for pollutant removal.
\end{abstract}

Keywords: ammonia removal; hydrogen sulfide removal; Illumina MiSeq; microbial community; wastewater treatment facility

\section{Introduction}

Wastewater treatment is an essential process that is directly linked to human health and environmental issues [1]. The construction of wastewater treatment systems and the development of facilities and technologies have protected humans from waterborne diseases [2] Additionally, the destruction and pollution in aquatic ecosystems, such as eutrophication and toxic algal blooms, that may occur due to wastewater could be prevented through improved wastewater treatment [3]. With the development of industry, the amount of wastewater discharged by humanity has increased, and the types of wastewater have also diversified [4]. As the types of wastewater have diversified to keep pace with these changes, 
various approaches to wastewater treatment are required [4]. As such, it is vital to conduct research on efficient wastewater treatment [5], from which various wastewater treatment facilities and systems can be developed [5,6]. Physical methods that depend on particle sizes, such as sedimentation or filtration, are introduced [7]. By such facilities and systems, suspended solids and debris can be separated from wastewater [8]; however, there were limits to chemicals that could not be removed through physical filtration [9]. In wastewater, not only a large number of pollutants such as nitrogen and phosphorus compounds exist, but also chemicals that cause odor vary depending on the wastewater source $[10,11]$. Therefore, it was necessary to supplement the removal of pollutants, including odor-causing chemicals $[8,12]$. To remove pollutants that cannot be removed by physical filtration, a biological purification process was applied [12]; this process uses microbes capable of decomposing pollutants, including odor-causing substances [13], and it enables the decomposition of both odor-related compounds and some toxic substances [14].

To remove pollutants contained in wastewater, nitrogen and phosphorus-related chemicals were the primary evaluation criteria [15]. For pollutant removal to meet the evaluation criteria, various microorganisms, including denitrifying bacteria and microalgae, were utilized, and nitrogen and phosphorus could be isolated from the wastewater [16,17]. However, although the successful removal of nitrogen and phosphorus, odors were not controlled due to odor-causing substances in some cases [18]. There are various odor-causing substances, and the types of microorganisms that decompose them are limited [19,20]. In wastewater, many types of odor-causing substances exist, including VFAs, ammonia, and hydrogen sulfide $[13,21]$; thus, various types of microorganisms are used to decompose and purify these substances $[13,22]$. Previous studies have shown that several bacterial species of the genus Dietzia have the ability to decompose VFAs [23], while some bacterial species of Alcaligenaceae and Oleiphilaceae are effective in removing ammonia [24-26], and various bacterial strains belonging to genera, such as Comamonas, Guyparkeria, and Aquamicrobium or the family Thioalkalibacteraceae can be used to treat hydrogen sulfide [27-33]. These findings have shown the basis for applying functional microorganisms in wastewater treatment facilities [23,25,27,33]. However, given that microbial communities can change because of environmental factors and seasonal changes, there remains a need for studies on microbial community characteristics and the functionality of single strains [34-36]. Many efforts to analyze the characteristics of the microbial community through metagenomic methods have been attempted by previous research [37]. These attempts have filled the insurmountable limitations of functional identification of microbial communities through culture-based assays [37,38].

In Korea, wastewater treatment is becoming increasingly essential because of the increase in the number and size of livestock farms [39]. Adequate removal of odor-causing chemicals is a critical issue for treating wastewater from livestock farms [40]. Therefore, a facility with a biofilter capable of removing contaminants, including VFAs, ammonia, and hydrogen sulfide, from various sewage was devised (Figure 1). To verify the effectiveness of this devised facility, the pollutant-removal function needs to be evaluated, and a deep knowledge of the pollutant-removal function requires an understanding of the microbial community. Therefore, in this study, the efficiency of the removal of odorcausing substances by livestock wastewater treatment facility was evaluated. Illumina MiSeq sequencing was used to reveal the relationship between the functionality of the biofilter system and the microbial community. Furthermore, this sequencing technique was used to compare the winter and summer microbial communities. Additionally, through comparison with culture-based analysis, Illumina MiSeq sequencing was shown to be a superior method for microbial community analysis. 

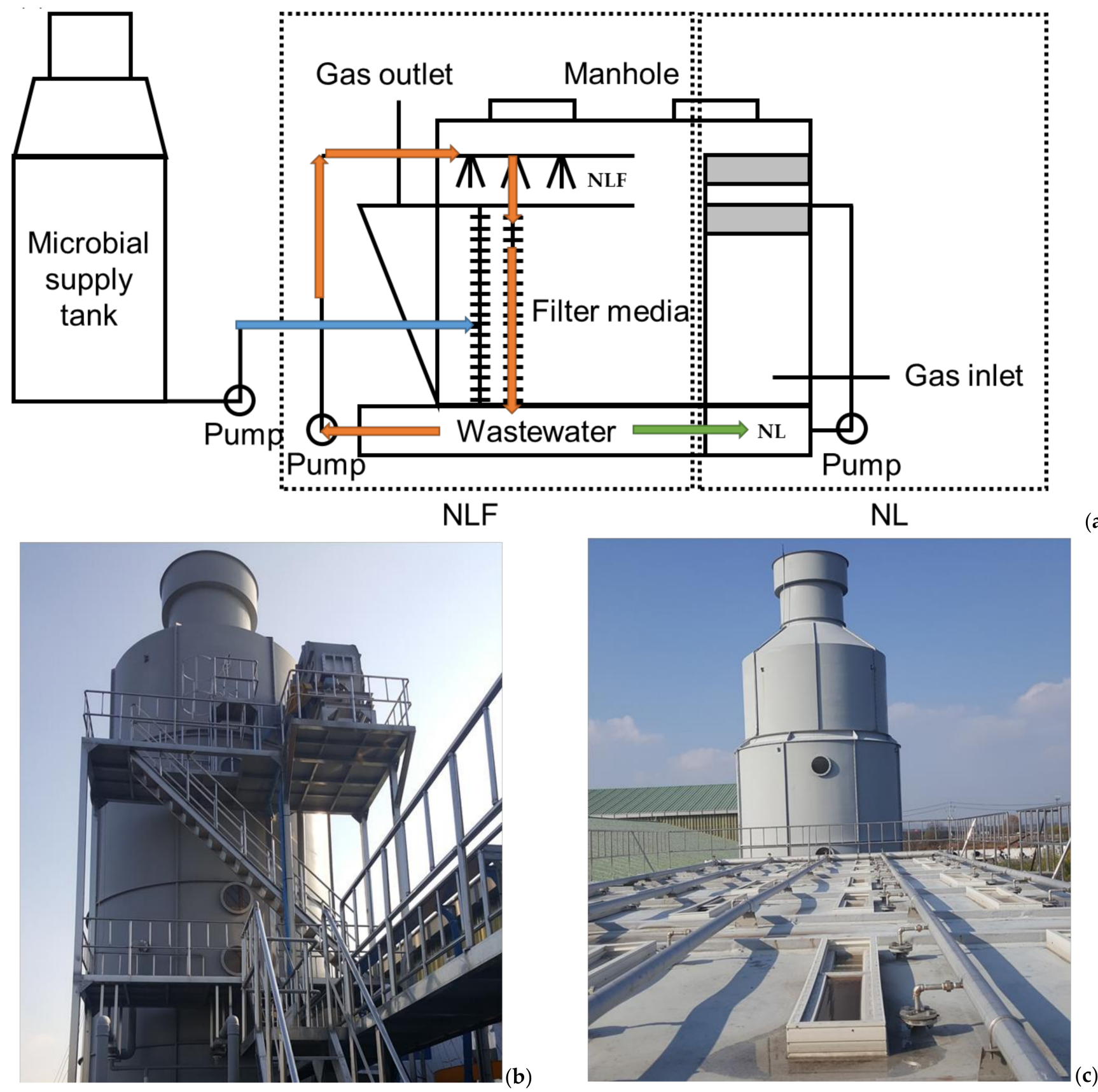

Figure 1. Schematic diagram of the wastewater treatment facility and images of the site facility (Nonsan Gyeryong Livestock cooperative organization, Natural Circulation Agricultural Center; $36^{\circ} 10^{\prime} 36.6^{\prime \prime} \mathrm{N} 127^{\circ} 03^{\prime} 10.4^{\prime \prime} \mathrm{E}$ ). (a) The facility is largely divided into an NLF area, where wastewater is treated, and an NL area, where treated wastewater is discharged; a microbial supply tank connected to the filter media of NLF is attached to the facility. Images of the facility show (b) the microbial supply tank and (c) the top of the treatment facility.

\section{Materials and Methods}

\subsection{Measurement of Ammonia}

The concentrations of ammonia were measured to confirm the ability of the wastewater treatment facility to remove pollutants; for this purpose, the methods for the spectrophotometric determination of ammonia were used [41]. To measure the ammonia concentration, $10 \mathrm{~L}$ of air samples were collected at the gas inlet and outlet of the wastewater treatment facility. The samples were injected into a container with $10 \mathrm{~mL}$ of boric acid solution $(5 \mathrm{~g} / \mathrm{L})$ and mixed for $10 \mathrm{~min}$ to allow the reaction with ammonia. Then, $5 \mathrm{~mL}$ of phenol-sodium 
nitroprusside solution (phenol concentration: $10 \mathrm{~g} / \mathrm{L}$; sodium nitroprusside concentration: $50 \mathrm{mg} / \mathrm{L}$ ) was added and mixed. To this mixture, $5 \mathrm{~mL}$ of $10 \%$ sodium hypochlorite solution was added and allowed to react for $1 \mathrm{~h}$ at room temperature. Then, the $\mathrm{OD}_{640}$ value of the reacted sample was measured [41], and the concentration of ammonia was calculated and compared to a standard solution ([ $\left.\mathrm{NH}_{4}\right]_{2} \mathrm{SO}_{4}$ concentration: $\left.0.295 \mathrm{~g} / \mathrm{L}\right)$ as follows:

$$
C=\frac{A}{V \times \frac{298}{273+t} \times \frac{P}{760}},
$$

where $C$ is the atmospheric ammonia concentration (ppm: $\mu \mathrm{mol} / \mathrm{mol}), A$ is the ammonia content of the sample for analysis $(\mu \mathrm{L}), V$ is the suction volume measured $(\mathrm{L}), t$ is the temperature $\left({ }^{\circ} \mathrm{C}\right)$, and $P$ is the atmospheric pressure during sampling $(\mathrm{mmHg})$.

\subsection{Measurement of Sulfur Compounds}

The concentrations of sulfur compounds were measured to confirm the ability of the wastewater treatment facility to remove pollutants; for this purpose, the packed gas chromatography methods were used [42]. To measure the concentration of sulfur compounds, $10 \mathrm{~L}$ of air samples was collected and condensed at $-180{ }^{\circ} \mathrm{C}$ using a low-temperature condensation tube [42]. For the analysis of concentrated samples, an A $6890 \mathrm{~N}$ gas chromatograph (Agilent Technologies Inc., Santa Clara, CA, USA) equipped with a $\beta \beta^{\prime}$-ODPN column ( $\beta \beta^{\prime}$-oxydipropionionitrile $25 \%$ coated on Chromosorb $W, 60 / 80$ mesh acid washed, and treated with DMCS) was used, and hydrogen sulfide, methanethiol, dimethyl sulfide, and dimethyl disulfide were measured as standard materials [43].

\subsection{Sample Collections}

The wastewater samples were collected from the two areas (NLF: wastewater in the biofilter; NL: wastewater after biofiltering) of the livestock wastewater treatment plant in Nonsan, Korea (Figure 1; Nonsan Gyeryong Livestock cooperative organization, Natural Circulation Agricultural Center: $36^{\circ} 10^{\prime} 36.6^{\prime \prime} \mathrm{N} 127^{\circ} 03^{\prime} 10.4^{\prime \prime} \mathrm{E}$ ). The investigated wastewater treatment facility is equipped with a system that circulates wastewater through a pump to maintain aerobic conditions. Wastewater flows into the facility daily, and it has a step-by-step structure that can be spatially separated from previously treated wastewater. The newly introduced wastewater and the previously treated wastewater are exposed to the biofilter through the circulation process. A biofilter is a fixed-type solid-state filter, and the biofilter is sprayed with a microbial culture provided from a microbial supply tank. The system is built in such a way that the microbial community formed on the surface of the biofilter can be involved in the process of treating wastewater exposed to the biofilter. Wastewater that has passed through a biofilter is evaluated for removal of pollutant before discharge, and wastewater from which the pollutant has been removed is discharged from the facility. NLF samples were collected from the biofilter of the investigated plant. The NLF samples included wastewater introduced into the plant, microbial culture from the microbial supply tank, and a biofilm formed on the surface of the biofilter. NL samples were collected at the discharge stage of the investigated plant after the wastewater treatment process was completed. The NL samples included only effluents that had undergone wastewater treatment with biofilters. The $1 \mathrm{~L}$ bottle samples were collected at each site. Samples were collected in June 2019 and January 2020 to identify changes and differences in the microbial community with seasonal and temporal changes.

\subsection{DNA Extraction and Pyrosequencing}

The DNA samples for pyrosequencing were extracted from the liquid samples. A FastDNA SPIN Kit for Soil (MP Biomedicals, Santa Ana, CA, USA) was used for DNA extraction according to the manufacturers' protocol. The extracted DNA was amplified by barcoded fusion primers, targeting the V3-V4 region of the $16 \mathrm{~S}$ rRNA gene [44]. The primer set consisted of 341F (5'-TCGTCGGCAGCGTCAGATGTGTATAAGAGACAGCCTACGGGNGGCWGCAG-3'; sequence indicates the target region primer) and 805R (5'-GTCTCGTGGG- 
CTCGG-AGATGTGTATAAGAGACAGGACTACHVGGGTATCTAATCC-3'). PCR amplification was conducted under the following conditions: initial denaturation for $3 \mathrm{~min}$ at $95^{\circ} \mathrm{C}$, 25 additional cycles of denaturation for $30 \mathrm{~s}$ at $95^{\circ} \mathrm{C}$, primer annealing for $30 \mathrm{~s}$ at $55^{\circ} \mathrm{C}$, extension for $30 \mathrm{~s}$ at $72{ }^{\circ} \mathrm{C}$, and final elongation for $5 \mathrm{~min}$ at $72{ }^{\circ} \mathrm{C}$. To attach the Illumina NexTera barcode, secondary amplification was also performed. A primer set consisting of i5 forward primer (5'-AATGATACGGCGACCACCGAGATCTACACXXXXXXXXTCGTCGGCAGCGTC- $3^{\prime}$; $X$ indicates the barcode region) and i7 reverse primer (5'-CAAGCAGAAGACGGCATACGAGAT-XXXXXXXX-GTCTCGTGGGCTCGG-3') was used. The conditions for amplification were the same, except that eight amplification cycles were used. The PCR product was electrophoresed to select the DNA samples longer than $300 \mathrm{bp}$, and a $1 \%$ agarose gel and gel doc system (BioRad, Hercules, CA, USA) was applied. The amplified products were purified, and the short fragments were removed with CleanPCR (CleanNA). Then, the length of the products was checked using Agilent 2100 Bioanalyzer (Agilent Technologies, Santa Clara, CA, USA). Finally, pyrosequencing was performed by ChunLab, Inc. (Seoul, Korea) with an Illumina MiSeq sequencing system (Illumina, San Diego, CA, USA).

\subsection{Sequence Processing and Taxonomic Analysis}

The raw pyrosequencing reads were qualified, and the low-quality (average quality value $<25$ ) reads were filtered and trimmed by the inhouse program of ChunLab (Seoul, Korea). The non16S rRNA encoding amplicons were detected by HMMER hmmsearch program (HmmerWeb version 3.3, Cambs., UK) [45], and the sequences were denoised using DUDE-Seq [46]. For taxonomic assignment, the EzBioCloud database was used with USEARCH (8.1.1861_i86linux32) [47]. The nonchimeric 16S rRNA database from EzBioCloud was used to detect chimera on reads with $<97 \%$ best hit similarity rate. Then, the sequence data were clustered using CD-HIT and UCLUST [47,48]. All statistical analyses of the bacterial communities were conducted with the CLcommunity software (CLcommunity ${ }^{\mathrm{TM}}$ Version 3.42, ChunLab, Inc., Seoul, Korea). The operational taxonomic units (OTUs) were defined with the CD-Hit program (CD-Hit-est, La Jolla, CA, USA) at 3\% sequence dissimilarity [49]. The species richness and species diversity indices, including Chao1, Shannon, and Simpson indices, were calculated using the Mothur platform [50].

\subsection{Community Analysis Based on Lab-Scale Cultivation}

First, $10 \mu \mathrm{L}$ of each wastewater sample was spread on an agar plate (R2A medium with $15 \mathrm{~g} / \mathrm{L}$ of agarose) [51]. Then, cultivation was done in an incubation room at $30^{\circ} \mathrm{C}$. When bacterial colonies appeared on the plates, they were aseptically transferred to a fresh R2A medium. Each transferred bacterial strain was cultured on an orbital shaker at 180 rpm in an incubation room; then, molecular identification of each strain was performed using the 16S rRNA gene [44]. Based on the quantification and molecular identification of bacterial strains, the composition that could be cultured from wastewater was analyzed. Phylogenetic analysis was performed using the software package MEGA (version 7.0, PA, USA) [52,53]. The sequencing data were aligned using ClustalW (Version 2.0, Kyoto, Japan) and incorporated into MEGA. Based on the Bayesian information criterion, the best-fit nucleotide substitution model was selected [54]; a phylogenetic tree was constructed based on this model [55].

\subsection{Statistical Analysis}

We compared the individual data using Student's $t$-test, with $p$ values $<0.05$ considered to be statistically significant. All experiments were performed at least in triplicate, and all results are expressed as means \pm standard deviations.

\section{Result and Discussion}

\subsection{Pollutant Purification Functionality and Community Diversity of Biofilter Facilities}

To evaluate the pollutant purification functionality of the facility, the difference between the ammonia and hydrogen sulfide in the influent (NLF: wastewater in biofilter) 
and effluent (NL: wastewater after biofiltering) was measured (Table 1). In June 2019, the influent contained 15.30 and 10.58 ppm of ammonia and hydrogen sulfide, respectively; the effluent contained 2.00 and $0.03 \mathrm{ppm}$ of ammonia and hydrogen sulfide, respectively. Thus, in this period, $\sim 86.93 \%$ of ammonia and $\sim 99.72 \%$ of hydrogen sulfide were removed from the wastewater by the facility. On the other hand, in January 2020, the ammonia and hydrogen sulfide rates decreased to $5.50 \mathrm{ppm}$ (removal rate: $64.05 \%$ ) and $1.01 \mathrm{ppm}$ (removal rate: $94.12 \%$ ), respectively. Therefore, the pollutant-removal rate in January 2020 was lower than in June 2019, particularly for ammonia. However, a high removal rate for hydrogen sulfide $(>90 \%)$ was observed in both periods.

Table 1. Pollutant concentrations, sequencing results for OTUs, and statistical diversity analysis of wastewater samples from the NLF and NL areas of the wastewater treatment facility shown in Figure 1.

\begin{tabular}{|c|c|c|c|c|c|}
\hline \multirow{2}{*}{\multicolumn{2}{|c|}{ Evaluation Item }} & \multicolumn{2}{|c|}{ June 2019} & \multicolumn{2}{|c|}{ January 2020} \\
\hline & & \multirow{3}{*}{$\begin{array}{c}\text { NLF } \\
15.30 \pm 0.00 \\
10.58 \pm 0.38\end{array}$} & \multirow{3}{*}{$\begin{array}{c}\text { NL } \\
2.00 \pm 0.00 \\
0.03 \pm 0.01\end{array}$} & \multirow{3}{*}{$\begin{array}{c}\text { NLF } \\
15.30 \pm 0.14 \\
17.17 \pm 9.93 \\
\end{array}$} & \multirow{3}{*}{$\begin{array}{c}\text { NL } \\
5.50 \pm 1.41 \\
1.01 \pm 0.40\end{array}$} \\
\hline & Ammonia (ppm) & & & & \\
\hline Pollutant concentration & Hydrogen sulfide (ppm) & & & & \\
\hline \multirow{2}{*}{ Sequencing results } & Validated reads & 23,958 & 43,833 & 52,922 & 60,290 \\
\hline & Number of OTUs ${ }^{\text {a }}$ & 740 & 1884 & 852 & 991 \\
\hline \multirow{4}{*}{ Diversity indicators } & Chao1 $^{\mathrm{b}}$ & 748.23 & 1891.03 & 857.14 & 997.21 \\
\hline & Shannon ${ }^{c}$ & 3.94 & 4.50 & 3.81 & 4.07 \\
\hline & Simpson $^{\mathrm{d}}$ & 0.08 & 0.08 & 0.07 & 0.05 \\
\hline & Goods Coverage ${ }^{\mathrm{e}}$ & 99.73 & 99.77 & 99.9 & 99.9 \\
\hline
\end{tabular}

a OTUs: operational taxonomic units. ${ }^{\mathrm{b}}$ Chao1: species richness estimation. ${ }^{\mathrm{c}}$ Shannon: Shannon diversity index (>0, higher is more diverse).

$\mathrm{d}$ Simpson: Simpson diversity index $\left(0-1,1=\right.$ most simple). ${ }^{\mathrm{e}}$ Goods coverage: 1 -(number of singleton OTUs/number of sequences);

$1=100 \%$ coverage.

The sequencing results and diversity indicator values are shown in Table 1 . The number of validated reads tended to be higher in January 2020 (NLF: 52,922; NL: 60,290) than in June 2019 (NLF: 23,958; NL: 43,833), and in both periods, the number of reads in NL was higher than in NLF. In June 2019, the highest number of OTUs in NL (1884) and the lowest number of OTUs in NLF (740) were recorded. In addition, the number of OTUs was lower in NLF than in NL in both June 2019 and January 2020. The trend of species richness (Chao1) in NLF and NL was similar to that of the OTUs. The highest Chao1 value was measured in NL in June 2019 (1891.03), and the lowest was measured in NLF in June 2019 (748.23). Furthermore, species richness was lower in NLF than in NL in both periods. In contrast, there was a little difference between the species diversity in NL and NLF, and both had higher Shannon and Simpson values in June 2019 than in January 2020, but the difference was not significant.

In summary, species diversity was similar despite the differences in time (June 2019 vs. January 2020) and space (NLF vs. NL) and the scale and species richness of the microbial community. In addition, the results from both periods showed that ammonia and hydrogen sulfide were effectively removed by the facility, with pollutant removal being more efficient in June 2019; despite this, the microbial community was larger in January 2020 (as shown by the higher validated reads in both NLF and NL), which suggests that the pollutant-removal rate was not proportional to the scale of the total microbial group [56,57]. In NLF, although species richness was the lowest in June 2019, species diversity was the highest in the same period. Given that the diversity of the microbial community in NLF (in which pollutants are primarily removed) was the highest in June 2019, the microbial community diversity is apparently related to pollutant-removal efficiency $[56,57]$. Therefore, the composition of the microbial community is related to the characteristics of the microbial group, and the analysis of both composition and characteristics is required to understand the pollutantremoval functionality of wastewater facilities [56,57]. 


\subsection{Taxonomic Composition of the Microbial Community and Pollutant Purification-Related Strains}

The taxonomic composition of the microbial community at the phylum and genus levels are shown in Figure 2. The microbial community of the analyzed NLF and NL samples consisted of eight phyla (Actinobacteria, Bacteroidetes, Firmicutes, Gemmatimonadetes, Parcubacteria, Proteobacteria, Rhodothermaeota, and Saccharibacteria). In June 2019 , the microbial community in NLF was dominated by Proteobacteria $(76.23 \%)$, while three other phyla had a relative abundance of $>5 \%$ (Bacteroidetes: $7.59 \%$; Parcubacteria: $6.59 \%$; Firmicutes: $5.87 \%$ ). In this period, the microbial community of NL was dominated by Firmicutes $(67.13 \%)$, while three other phyla had a relative abundance of $>5 \%$ (Bacteroidetes: 12.11\%; Proteobacteria: 7.73\%; Rhodothermaeota: 6.74\%). Unlike in June 2019, the microbial community composition in NLF and NL was similar in January 2020. In both NLF and NL, there were no phyla with a relative abundance of $>50 \%$, but three phyla had a relative abundance $>20 \%$ (Bacteroidetes, Firmicutes, and Proteobacteria); these three phyla accounted for $>90 \%$ of the microbial community in NLF (92.54\%) and NL $(92.07 \%)$ in January 2020. In all samples from each study period, Bacteroidetes, Firmicutes, and Proteobacteria always had a relative abundance $>5 \%$, whereas Actinobacteria always had a relative abundance $>1 \%$.

At the genus level, ten genera (Flavobacteriaceae, Alcaligenaceae, Pseudogracilibacillus, Limnochordaceae, Oleiphilaceae, Sphingobacterium, Guyparkeria, Moheibacter, Thioalkalibacteraceae, and Rubricoccaceae) with a relative abundance of $>5 \%$ were identified. The sum of the relative abundances of these 10 genera was $>50 \%$ in all samples analyzed in June 2019 (NLF: 65.38\%; NL: 58.17\%) and January 2020 (NLF: 76.96\%; NL: 75.64\%). For the samples from June 2019, the microbial community of NLF was dominated by Oleiphilaceae $(40.89 \%)$ and Thioalkalibacteraceae $(12.91 \%)$, and the microbial community of NL was dominated by Limnochordaceae (41.83\%), Moheibacter (9.67\%), and Rubricocccaceae (5.50\%). For samples from January 2020, the microbial communities of NLF and NL were dominated by Flavobacteriaceae (NLF: 23.83\%; NL: 23.59\%), Alcaligenaceae (NLF: 22.48\%; NL: 21.75\%), Pseudogracilibacillus (NLF: 19.01\%; NL: 18.26\%), Sphingobacterium (NLF: 5.44\%; NL: 5.99\%), and Guyparkeria (NLF: 5.96\%; NL: 5.84\%). In June 2019, Oleiphilaceae, Limnochordaceae, Moheibacter, Thioalkalibacteraceae, and Rubricoccaceae dominated, while in January 2020, Flavobacteriaceae, Alcaligenaceae, Pseudogracilibacillus, Sphingobacterium, and Guyparkeria dominated.

The four phyla with relatively high abundance, namely, Actinobacteria, Bacteroidetes, Firmicutes, and Proteobacteria, contained families/genera that were expected to belong to functional strains related to pollutant removal (Table 2, Supplementary Tables S1 and S2) [58-61]. In January 2020, the relative abundance of Oleiphilaceae (40.89\%) and Thioalkalibacteraceae $(12.91 \%)$, families belonging to Proteobacteria, was high in NLF; these two families comprised $53.80 \%$ of the NLF microbial community. By contrast, the microbial community of NL was mainly composed of Moheibacter $(9.67 \%)$ and Limnochordaceae $(41.83 \%)$, a genus and family belonging to Bacteroidetes and Firmicutes, respectively; they comprised $51.50 \%$ of the community based on abundance. In January 2020, two families, Alcaligenaceae and Flavobacteriaceae, and one genus, Pseudogracilibacillus, had abundances of $>10 \%$. In addition, $>75 \%$ of the microbial communities in NLF $(76.74 \%)$ and NL $(75.45 \%)$ were made up of five families or genera with abundances of $>5 \%$. In comparative analysis, there were differences between the samples from June 2019 and January 2020. Unlike in January 2020, there was no common dominant family/genus between NLF and NL in June 2019. Between the periods, there were also differences in the trends of dominant family/genera abundance. In June 2019, two families/genera had $>5 \%$ abundance, and one had $>40 \%$ abundance. On the other hand, in January 2020, there were five dominant families/genera with $5-25 \%$ abundance. 


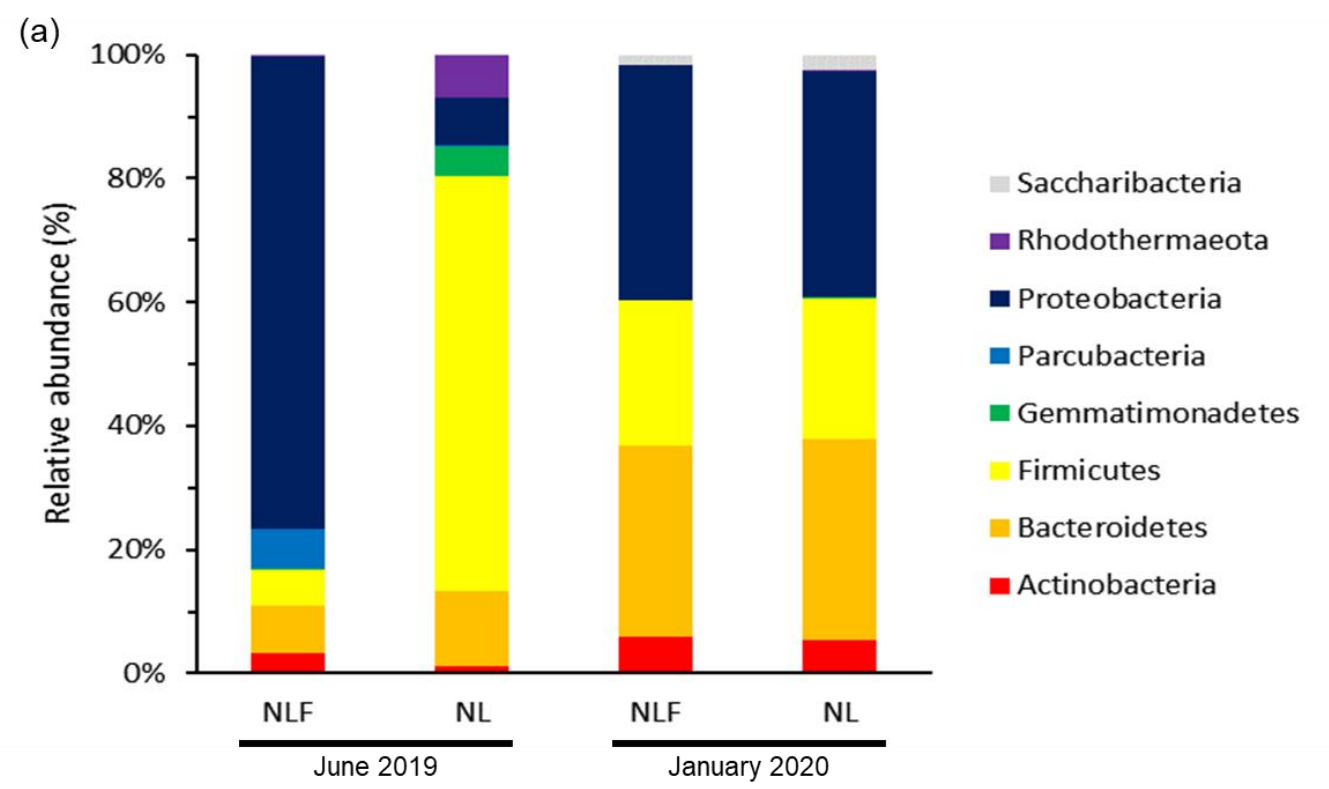

(b)

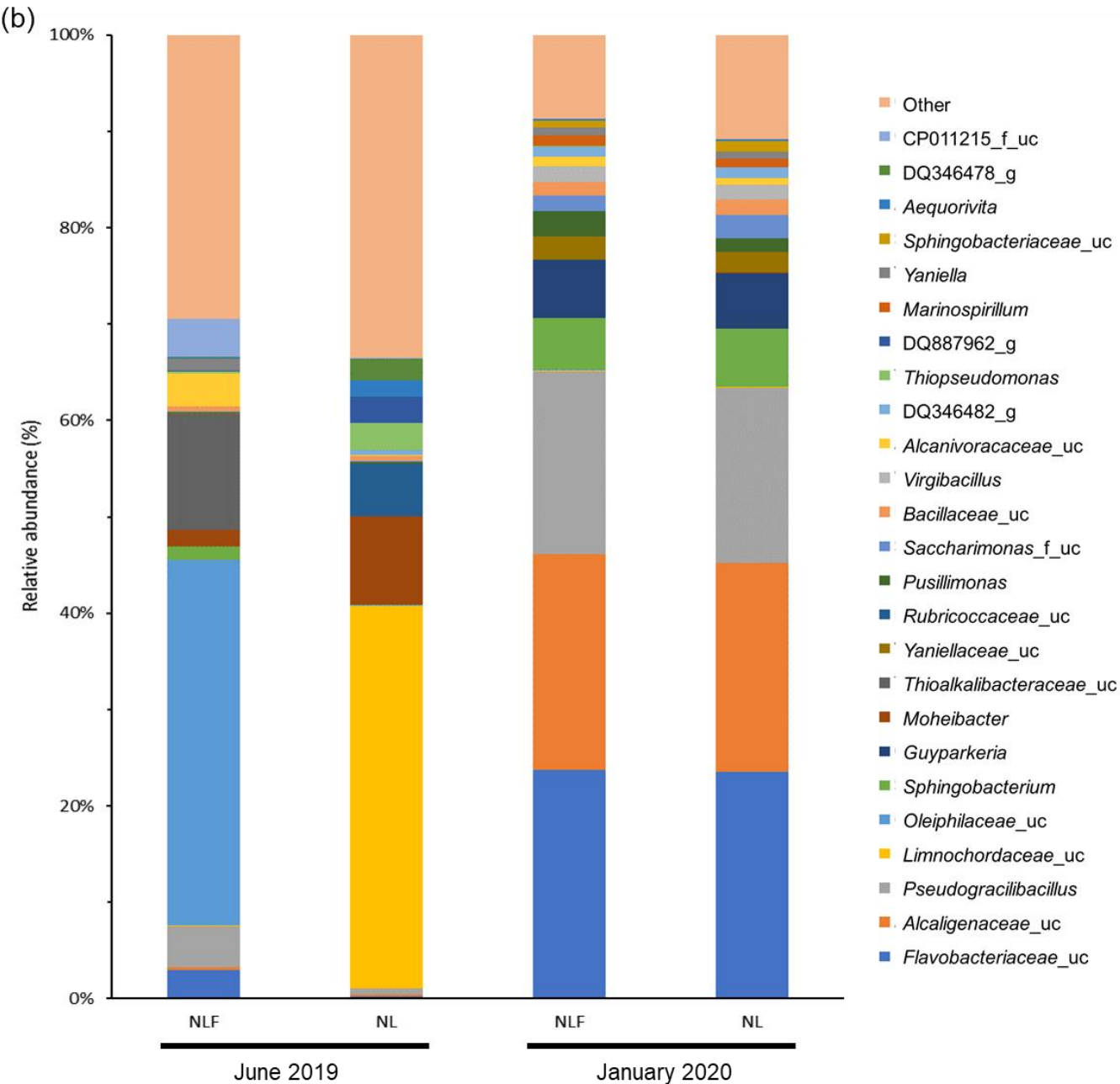

Figure 2. Taxonomic composition of the prokaryotic microbial phyla in the NLF and NL areas of the wastewater treatment facility shown in Figure 1. The relative abundance of bacterial (a) phyla and (b) genus are shown. 
Table 2. Relative abundance of dominant and functional strains in NLF and NL samples.

\begin{tabular}{|c|c|c|c|c|c|c|c|c|c|c|c|}
\hline \multirow{3}{*}{\multicolumn{2}{|c|}{$\begin{array}{l}\text { Bacterial Group } \\
\text { Characteristic Classification }\end{array}$}} & \multirow{2}{*}{\multicolumn{2}{|c|}{ Taxonomy }} & \multicolumn{4}{|c|}{ June 2019} & \multicolumn{4}{|c|}{ January 2020} \\
\hline & & & & \multicolumn{2}{|c|}{ NLF } & \multicolumn{2}{|c|}{ NL } & \multicolumn{2}{|c|}{ NLF } & \multicolumn{2}{|c|}{ NL } \\
\hline & & Phylum & Genus & Freq $^{a}$ & $\%{ }^{b}$ & Freq $^{a}$ & $\%^{b}$ & Freq $^{a}$ & $\%^{b}$ & Freq $^{a}$ & $\%^{b}$ \\
\hline \multirow{5}{*}{\multicolumn{2}{|c|}{ Dominant strain }} & Bacteroidetes & Flavobacteriaceae & 701 & 3.16 & 96 & 0.23 & 12,558 & 23.83 & 14,166 & 23.59 \\
\hline & & Bacteroidetes & Moheibacter & 421 & 1.89 & 4025 & 9.67 & 6 & 0.01 & 6 & 0.01 \\
\hline & & Bacteroidetes & Sphingobacterium & 319 & 1.44 & 0 & 0.00 & 2865 & 5.44 & 3599 & 5.99 \\
\hline & & Firmicutes & Pseudogracilibacillus & 997 & 4.49 & 284 & 0.68 & 10,019 & 19.01 & 10,966 & 18.26 \\
\hline & & Firmicutes & Limnochordaceae & 44 & 0.20 & 17,416 & 41.83 & 41 & 0.08 & 59 & 0.10 \\
\hline \multirow{7}{*}{$\begin{array}{l}\text { Functional } \\
\text { strain }\end{array}$} & \multirow{2}{*}{$\begin{array}{l}\text { Strain related to } \\
\text { ammonia removal }\end{array}$} & Proteobacteria & Alcaligenaceae & 89 & 0.40 & 98 & 0.24 & 11849 & 22.48 & 13,063 & 21.75 \\
\hline & & Proteobacteria & Oleiphilaceae & 9084 & 40.89 & 7 & 0.02 & 67 & 0.13 & 30 & 0.05 \\
\hline & $\begin{array}{l}\text { Strain related to } \\
\text { volatile fatty acid } \\
\text { removal }\end{array}$ & Actinobacteria & Dietzia & 0 & 0.00 & 8 & 0.02 & 24 & 0.05 & 20 & 0.03 \\
\hline & \multirow{4}{*}{$\begin{array}{l}\text { Strain related to } \\
\text { hydrogen sulfide } \\
\text { removal }\end{array}$} & Proteobacteria & Comamonas & 159 & 0.72 & 0 & 0 & 0 & 0 & 0 & 0 \\
\hline & & Proteobacteria & Thioalkalibacteraceae & 2869 & 12.91 & 0 & 0 & 5 & 0.01 & 21 & 0.04 \\
\hline & & Proteobacteria & Guyparkeria & 0 & 0 & 0 & 0 & 3153 & 5.98 & 3519 & 5.86 \\
\hline & & Proteobacteria & Aquamicrobium & 102 & 0.46 & 5 & 0.01 & 0 & 0 & 6 & 0.01 \\
\hline
\end{tabular}

${ }^{a}$ Frequency by which bacteria was detected in each sample. ${ }^{b}$ Relative abundance.

According to the Illumina MiSeq analysis results, the taxonomic composition of NLF and NL mainly consisted of microorganisms belonging to Bacteroidetes, Firmicutes, and Proteobacteria (Figure 2), and the families/genera with the highest abundance also belonged to these phyla (Table 2). The microbial community in NLF and NL contained several families/genera involved in the removal of pollutants, such as VFAs, ammonia, and hydrogen sulfide $[23,25-28,30,33]$. In particular, some of the highly abundant families/genera belonging to Proteobacteria are known to be related to the removal of ammonia (Alcaligenaceae and Oleiphilaceae) and hydrogen sulfide (Aquamicrobium, Comamonas, Guyparkeria, and Thioalkalibacteraceae) $[25-28,30,33]$. The presence of these families/genera suggests the possibility that pollutants could be removed by this microbial community [23,33]. The analysis of the facility also showed a correlation between the rate of pollutant removal and the composition of the NLF microbial community (Tables 1 and 2; Figure 2). In June 2019, when the removal rate of ammonia $(86.93 \%)$ and hydrogen sulfide $(99.72 \%)$ was high, the abundance of families/genera related to pollutant removal in the microbial community of NLF (Oleiphilaceae: 40.89\%; Thioalkalibacteraceae: 12.91\%) was higher than in January 2020 (Alcaligenaceae: 22.48\%; Guyparkeria: 5.98\%) [25,26,28,30]. Therefore, the higher pollutant-removal rate in June 2019 relative to that in January 2020 may have been due to the composition of the microbial community and its associated characteristics.

\subsection{The Effectiveness of Illumina MiSeq for Microbial Community Analysis Compared to the Culture-Based Analysis}

To validate the Illumina MiSeq results, a culture-based analysis of the microbial community was also conducted (Tables 1 and 2). From NLF and NL samples, 56 and 13 species of bacteria were purely isolated, respectively. The strains isolated from NLF included, in order of abundance, those from Alcaligenes (13.09\%), Dietzia (11.71\%), Aquamicrobium (8.28\%), Comamonas (7.59\%), Sinimarinibacterium (6.89\%), and Pseudomonas (5.52\%). Most of the 13 species isolated from NL belonged to the genus Bacillus $(81.24 \%)$, including B. velezensis $(34.37 \%)$, B. amyloliquefaciens $(15.62 \%)$, Bacillus sp. $(12.49 \%)$, and B. safensis (6.24\%). The commonly separated species from NLF and NL were B. subtilis, B. velezensis, Mesorhizobium sp., and Staphylococcus hominis (the latter two had $100 \%$ bootstrap probabilities). By contrast, B. subtilis and B. velezensis were divided into groups isolated from NLF and NL (Figure 3). 


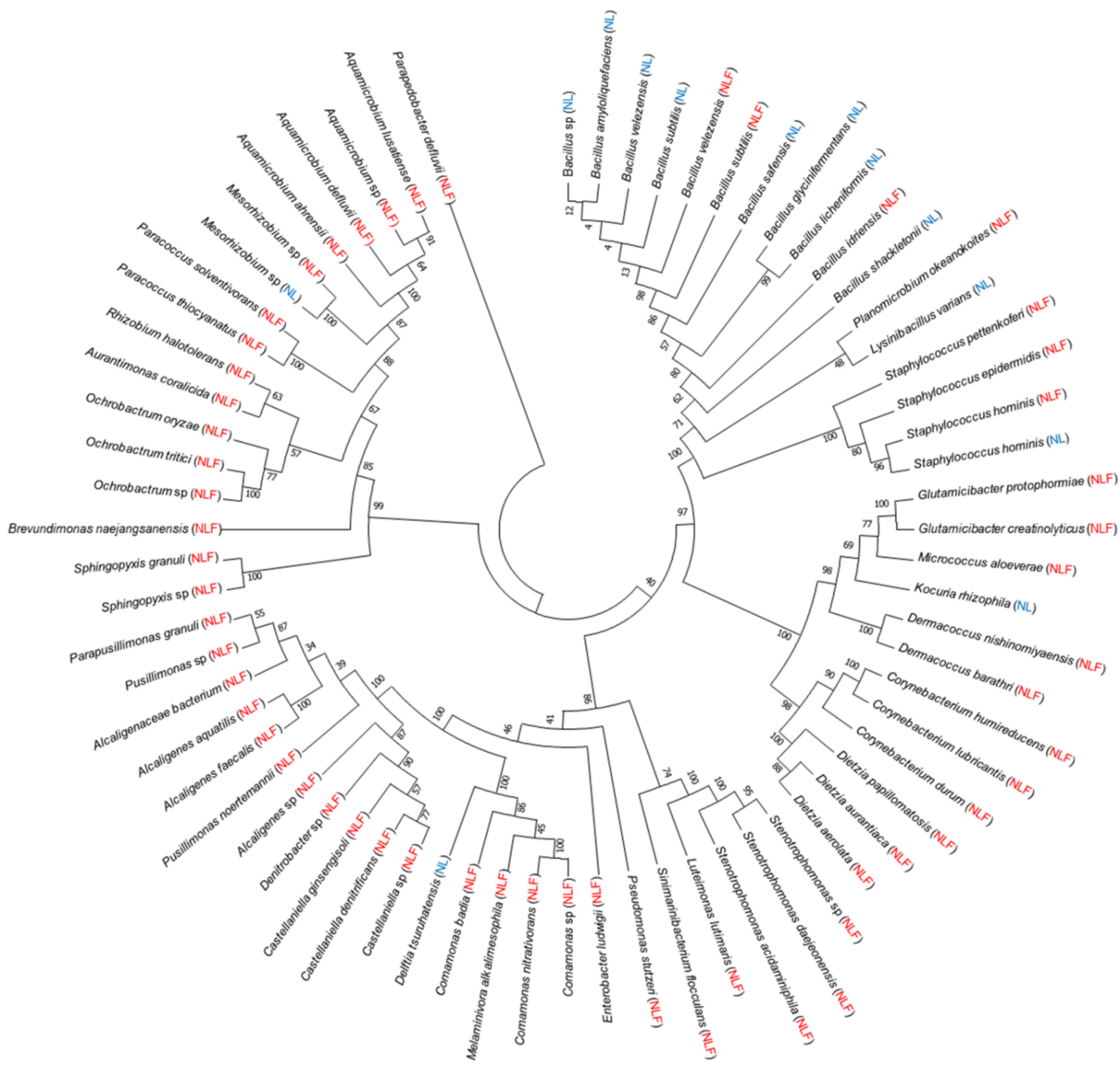

Figure 3. Molecular phylogenetic relationship of bacterial strains isolated from the NLF and NL areas of the wastewater treatment facility shown in Figure 1. The relationship between the 69 strains isolated from NLF (marked in red: 56 species) and NL (marked in blue: 13 species) is shown in a phylogenetic tree. The numbers at the nodes indicate the bootstrap probabilities ( $>50 \%)$ of the ML analyses (1000 replicates).

Through Illumina MiSeq, 740-1884 OTUs were identified in NLF and NL (Table 1); however, only 56 and 13 species were identified from NLF and NL by culture-based methods, respectively (Tables 3 and 4). Moreover, although Limnochordaceae and Oleiphilaceae had abundances $>40 \%$ in the microbial community, none of the isolated species belonged to these families. Therefore, there are clear limitations in analyzing the composition and structure of microbial communities through a culture-based analysis [62,63]. Despite these limitations, this analysis remains necessary to understand the characteristics of these communities [64]. For example, B. subtilis and B. velezensis were both isolated from NLF and $\mathrm{NL}$; however, the phylogenetic analysis showed that the similarity between the same species in different areas had decreased (Figure 3). Thus, even the same species can differ genetically and physiologically [65-67]. Overall, we suggest that Illumina MiSeq should 
be used as a more effective tool than a culture-based analysis to analyze the composition and structure of microbial communities. Nevertheless, a culture-based analysis should accompany Illumina MiSeq analysis to investigate the detailed differences in the genetic characteristics of individual microbial community members.

Table 3. Abundance of bacterial strains in NLF samples identified through a culture-based analysis.

\begin{tabular}{|c|c|c|c|c|}
\hline Taxonomic Affinity & Closest Match & $\begin{array}{c}\text { GenBank Accession } \\
\text { Number }\end{array}$ & $\begin{array}{c}\text { Sequence Similarity } \\
(\%)\end{array}$ & Abundance (\%) \\
\hline Alcaligenaceae bacterium & Alcaligenaceae bacterium & MH553029 & 99 & 0.69 \\
\hline Alcaligenes aquatilis & Alcaligenes aquatilis & JX986974 & 100 & 0.69 \\
\hline Alcaligenes faecalis & Alcaligenes faecalis & AUBT01000026 & 99 & 11.71 \\
\hline Alcaligenes sp. & Alcaligenes sp. & DQ421393 & 98 & 0.69 \\
\hline Aquamicrobium ahrensii & Aquamicrobium ahrensii & AM884149 & 100 & 0.69 \\
\hline Aquamicrobium defluvii & Aquamicrobium defluvii & KU163265 & 99 & 1.38 \\
\hline Aquamicrobium lusatiense & Aquamicrobium lusatiense & KM210272 & 99 & 5.52 \\
\hline Aquamicrobium sp. & Aquamicrobium sp. & LN881594 & 99 & 0.69 \\
\hline Aurantimonas coralicida & Aurantimonas coralicida & АТХК01000033 & 100 & 0.69 \\
\hline Bacillus idriensis & Bacillus idriensis & FR682742 & 99 & 3.45 \\
\hline Bacillus subtilis & Bacillus subtilis & AMXN01000021 & 99 & 0.69 \\
\hline Bacillus velezensis & Bacillus velezensis & AY603658 & 99 & 0.69 \\
\hline $\begin{array}{l}\text { Brevundimonas } \\
\text { naejangsanensis }\end{array}$ & $\begin{array}{l}\text { Brevundimonas } \\
\text { naejangsanensis }\end{array}$ & СР015614 & 99 & 0.69 \\
\hline Castellaniella denitrificans & Castellaniella denitrificans & U82826 & 99 & 0.69 \\
\hline Castellaniella ginsengisoli & Castellaniella ginsengisoli & EU873313 & 99 & 1.38 \\
\hline Castellaniella sp. & Castellaniella sp. & KM210263 & 100 & 1.38 \\
\hline Comamonas badia & Comamonas badia & NR_041011 & 94 & 1.38 \\
\hline Comamonas nitrativorans & Comamonas nitrativorans & AJ251577 & 100 & 3.45 \\
\hline Comamonas sp. & Comamonas sp. & JX271943 & 99 & 2.76 \\
\hline Corynebacterium durum & Corynebacterium durum & Z97069 & 99 & 0.69 \\
\hline $\begin{array}{l}\text { Corynebacterium } \\
\text { humireducens }\end{array}$ & $\begin{array}{l}\text { Corynebacterium } \\
\text { humireducens }\end{array}$ & СР005286 & 99 & 0.69 \\
\hline $\begin{array}{c}\text { Corynebacterium } \\
\text { lubricantis }\end{array}$ & $\begin{array}{c}\text { Corynebacterium } \\
\text { lubricantis }\end{array}$ & FM173119 & 96 & 0.69 \\
\hline Denitrobacter sp. & Denitrobacter sp. & EF471227 & 98 & 0.69 \\
\hline Dermacoccus barathri & Dermacoccus barathri & AY894328 & 100 & 0.69 \\
\hline $\begin{array}{c}\text { Dermacoccus } \\
\text { nishinomiyaensis }\end{array}$ & $\begin{array}{c}\text { Dermacoccus } \\
\text { nishinomiyaensis }\end{array}$ & MF952724 & 100 & 0.69 \\
\hline Dietzia aerolata & Dietzia aerolata & FM995533 & 99 & 8.26 \\
\hline Dietzia aurantiaca & Dietzia aurantiaca & FR821260 & 99 & 2.76 \\
\hline Dietzia papillomatosis & Dietzia papillomatosis & BCSL01000097 & 98 & 0.69 \\
\hline Enterobacter ludwigii & Enterobacter ludwigii & JTLO01000001 & 99 & 0.69 \\
\hline $\begin{array}{l}\text { Glutamicibacter } \\
\text { creatinolyticus }\end{array}$ & $\begin{array}{l}\text { Glutamicibacter } \\
\text { creatinolyticus }\end{array}$ & СР034412 & 100 & 0.69 \\
\hline $\begin{array}{l}\text { Glutamicibacter } \\
\text { protophormiae }\end{array}$ & $\begin{array}{l}\text { Glutamicibacter } \\
\text { protophormiae }\end{array}$ & X80745 & 100 & 1.38 \\
\hline Luteimonas lutimaris & Luteimonas lutimaris & NR_117455 & 99 & 0.69 \\
\hline $\begin{array}{l}\text { Melaminivora } \\
\text { alkalimesophila }\end{array}$ & $\begin{array}{l}\text { Melaminivora } \\
\text { alkalimesophila }\end{array}$ & JQ676982 & 99 & 2.07 \\
\hline Mesorhizobium sp. & Mesorhizobium sp. & KM210274 & 99 & 4.83 \\
\hline Micrococcus aloeverae & Micrococcus aloeverae & KF524364 & 99 & 1.38 \\
\hline Ochrobactrum oryzae & Ochrobactrum oryzae & AM041247 & 100 & 1.38 \\
\hline Ochrobactrum sp. & Ochrobactrum sp. & AM231041 & 100 & 2.07 \\
\hline Ochrobactrum tritici & Ochrobactrum tritici & AJ242584 & 100 & 0.69 \\
\hline Paracoccus solventivorans & Paracoccus solventivorans & NR_042714 & 99 & 1.38 \\
\hline Paracoccus thiocyanatus & Paracoccus thiocyanatus & NR_113663 & 100 & 1.38 \\
\hline Parapedobacter defluvii & Parapedobacter defluvii & KY612414 & 99 & 0.69 \\
\hline Parapusillimonas granuli & Parapusillimonas granuli & DQ466075 & 98 & 0.69 \\
\hline $\begin{array}{c}\text { Planomicrobium } \\
\text { okeanokoites }\end{array}$ & $\begin{array}{l}\text { Planomicrobium } \\
\text { okeanokoites }\end{array}$ & D55729 & 99 & 0.69 \\
\hline
\end{tabular}


Table 3. Cont.

\begin{tabular}{|c|c|c|c|c|}
\hline Taxonomic Affinity & Closest Match & $\begin{array}{c}\text { GenBank Accession } \\
\text { Number }\end{array}$ & $\begin{array}{c}\text { Sequence Similarity } \\
(\%)\end{array}$ & Abundance (\%) \\
\hline Pseudomonas stutzeri & Pseudomonas stutzeri & СР002881 & 99 & 5.52 \\
\hline Pusillimonas noertemannii & Pusillimonas noertemannii & NR_043129 & 99 & 0.69 \\
\hline Pusillimonas sp. & Pusillimonas sp. & FJ529031 & 99 & 1.38 \\
\hline $\begin{array}{l}\text { Sinimarinibacterium } \\
\text { flocculans }\end{array}$ & $\begin{array}{l}\text { Sinimarinibacterium } \\
\text { flocculans }\end{array}$ & HQ875491 & 94 & 6.89 \\
\hline Sphingopyxis granuli & Sphingopyxis granuli & BCUA01000059 & 100 & 1.38 \\
\hline Sphingopyxis sp. & Sphingopyxis sp. & СР026381 & 100 & 1.38 \\
\hline Staphylococcus epidermidis & Staphylococcus epidermidis & СР030246 & 99 & 0.69 \\
\hline Staphylococcus hominis & Staphylococcus hominis & X66101 & 99 & 0.69 \\
\hline Staphylococcus pettenkoferi & Staphylococcus pettenkoferi & AF322002 & 99 & 0.69 \\
\hline $\begin{array}{l}\text { Stenotrophomonas } \\
\text { acidaminiphila }\end{array}$ & $\begin{array}{l}\text { Stenotrophomonas } \\
\text { acidaminiphila }\end{array}$ & LDJO01000053 & 99 & 1.38 \\
\hline $\begin{array}{c}\text { Stenotrophomonas } \\
\text { daejeonensis }\end{array}$ & $\begin{array}{c}\text { Stenotrophomonas } \\
\text { daejeonensis }\end{array}$ & LDJP01000061 & 99 & 1.38 \\
\hline Stenotrophomonas sp. & Stenotrophomonas sp. & AB180662 & 98 & 1.38 \\
\hline Rhizobium halotolerans & Rhizobium halotolerans & JX307098 & 100 & 0.69 \\
\hline
\end{tabular}

Table 4. Abundance of bacterial strains in NL samples identified through a culture-based analysis.

\begin{tabular}{|c|c|c|c|c|}
\hline Taxonomic Affinity & Closest Match & $\begin{array}{c}\text { GenBank Accession } \\
\text { Number }\end{array}$ & Sequence Similarity (\%) & Abundance (\%) \\
\hline $\begin{array}{c}\text { Bacillus } \\
\text { amyloliquefaciens }\end{array}$ & $\begin{array}{c}\text { Bacillus } \\
\text { amyloliquefaciens }\end{array}$ & СР031424 & 100 & 15.62 \\
\hline $\begin{array}{c}\text { Bacillus } \\
\text { glycinifermentans }\end{array}$ & $\begin{array}{c}\text { Bacillus } \\
\text { glycinifermentans }\end{array}$ & СР023481 & 100 & 3.13 \\
\hline Bacillus licheniformis & Bacillus licheniformis & СР031126 & 100 & 3.13 \\
\hline Bacillus safensis & Bacillus safensis & СР010405 & 100 & 6.24 \\
\hline Bacillus shackletonii & Bacillus shackletonii & NR_025373 & 99 & 3.13 \\
\hline Bacillus sp. & Bacillus sp. & СР030937 & 100 & 12.49 \\
\hline Bacillus subtilis & Bacillus subtilis & СР029052 & 100 & 3.13 \\
\hline Bacillus velezensis & Bacillus velezensis & СР023075 & 100 & 34.37 \\
\hline Delftia tsuruhatensis & Delftia tsuruhatensis & MH478206 & 100 & 3.13 \\
\hline Kocuria rhizophila & Kocuria rhizophila & KP345929 & 100 & 6.24 \\
\hline Lysinibacillus varians & Lysinibacillus varians & AY082370 & 99 & 3.13 \\
\hline Mesorhizobium sp. & Mesorhizobium sp. & KM210274 & 99 & 3.13 \\
\hline Staphylococcus hominis & Staphylococcus hominis & СР014107 & 100 & 3.13 \\
\hline
\end{tabular}

\subsection{Relationship between Pollutant Purification and the Microbial Community}

The investigated facility demonstrated that livestock wastewater ammonia and hydrogen sulfide could be effectively removed (Table 1). Additionally, the Illumina MiSeq result expressed that pollutant-purification-related microbes existed in the biofilter (NLF) and treated effluent (NL) (Table 2). Interestingly, although ammonia and hydrogen sulfide were removed at both periods, June 2019 and January 2020, there were differences between the samples at both periods in the dominant species constituting the microbial community. The result supports that the purification capacity for ammonia and hydrogen sulfide can be maintained despite the changes in the species constituting the microbial community $[68,69]$. Changes in microbial species composition are of great concern in open-type purification facilities using microbes $[69,70]$. Due to the characteristic of the facility where microorganisms purify pollutants, the pollutant-purification ability depends on the characteristics of the microorganisms. The facility's utility can be determined by the characteristics of the microbial community [71,72]. Therefore, these facilities are sensitive to changes in the microbial community and require strategies for maintenance and control of the microbial species that can provide the desired function $[73,74]$. However, open-type facilities are 
vulnerable to the introduction of external microorganisms [75]. Furthermore, changes in wastewater properties, such as changes in organic carbon sources or the presence or absence of antibiotics, can change the composition of the microbial community [76]. Consequently, maintaining a particular species of microorganism is not easy. The reason wastewater treatment facilities can remain functional despite the difficulty in controlling changes in the microbial community is that microbial species with similar functions can replace the role of existing microbial species [69,74]. Our findings are also expected to be one of the cases in which microbial species have replaced functional microbial species in the microbial community with similar roles. It is desirable to maintain the pollutant-purification ability by constantly maintaining a certain functional microbial species, but considering this phenomenon, the most effective direction is to maintain the functionality by being replaced by a microbial species with similar function.

\section{Conclusions}

In this study, the relationship between pollutant removal and the microbial community in a wastewater treatment facility was evaluated. Both ammonia and hydrogen sulfide were removed by the facility, and the removal rate was the highest in June 2019. In the microbial community of NLF, in which the biofilters used to remove the pollutants were located, the scale (number of reads) and species richness (Chao1) were smaller and lower in June 2019 than in January 2020, but the species diversity was high in both periods. In the NLF area, the strains associated with the removal of ammonia and hydrogen sulfide existed at a higher abundance in June 2019 than in January 2020. Therefore, the increased presence of these pollutant-removing strains is likely associated with the high removal rate of ammonia and hydrogen sulfide. In conclusion, the effective pollutant removal of wastewater treatment facility depends on the microbial community of the biofilter, and a broad understanding of the microbial community can help effective wastewater treatment. Additionally, the efficiency of Illumina MiSeq sequencing was demonstrated by comparison with the culture-based analysis, in which only a few strains were identified. These findings provide an improved understanding of the relationship between the characteristics and compositions of microbial communities. In addition, our results promote the efficiency of Illumina MiSeq sequencing and its complementary potential with culture-based analysis.

Supplementary Materials: The following are available online at https: / www.mdpi.com/article / 10.3390/su13137358/s1, Table S1: Taxonomic composition and frequency of bacterial strains belonging to Proteobacteria in NLF and NL. Table S2: Taxonomic composition and frequency of bacterial strains belonging to Actinobacteria in NLF and NL.

Author Contributions: Formal analysis, D.-H.K.; methodology, H.-S.Y.; supervision, J.-G.K.; writingoriginal draft, Y.-S.K. All authors have read and agreed to the published version of the manuscript.

Funding: This research was supported by the Basic Science Research Program through the National Research Foundation of Korea (NRF), funded by the Ministry of Education (2016R1A6A1A05011910 and 2018R1D1A3B07049385), South Korea, and also by this research was supported by Kyungpook National University Development Project Research Fund 2018, Korea.

Institutional Review Board Statement: Not applicable.

Informed Consent Statement: Not applicable.

Data Availability Statement: Data sharing not applicable.

Acknowledgments: We thank Jae-Hong Park (Research Institute for Dok-do and Ulleung-do, Kyungpook National University) for helpful discussions. We also thank Ho-Sung Yoon (Advanced Bio-resource Research Center, Kyungpook National University) for assistance with the Materials and Methods.

Conflicts of Interest: The authors declare no conflict of interest. 


\section{References}

1. Luo, B.; Du, Y.; Han, W.; Geng, Y.; Wang, Q.; Duan, Y.; Ren, Y.; Liu, D.; Chang, J.; Ge, Y. Reduce health damage cost of greenhouse gas and ammonia emissions by assembling plant diversity in floating constructed wetlands treating wastewater. J. Clean. Prod. 2020, 244, 118927. [CrossRef]

2. Hussein, H.M. Environmental impact assessment of aquatic quality index for some private filtration stations in Diwaniyah governorate. Syst. Rev. Pharm. 2021, 12, 286-290.

3. Zhu, X.; Dao, G.; Tao, Y.; Zhan, X.; Hu, H. A review on control of harmful algal blooms by plant-derived allelochemicals. J. Hazard. Mater. 2020, 123403.

4. Hashem, S. Investigating the principles of water treatment and industrial wastewater. J. Eng. Indu. Res. 2021, 2, 44-55.

5. Liu, D.H.; Lipták, B.G. Wastewater Treatment; CRC Press: Boca Raton, FL, USA, 2020.

6. Wang, Y.; Li, L.; Xiong, R.; Guo, X.; Liu, J. Effects of aeration on microbes and intestinal bacteria in bioaerosols from the BRT of an indoor wastewater treatment facility. Sci. Total Environ. 2019, 648, 1453-1461. [CrossRef]

7. Mouratib, R.; Achiou, B.; El Krati, M.; Younssi, S.A.; Tahiri, S. Low-cost ceramic membrane made from alumina-and silica-rich water treatment sludge and its application to wastewater filtration. J. Eur. Ceram. Soc. 2020, 40, 5942-5950. [CrossRef]

8. Huang, J.L.; Wang, H.H.; Alam, F.; Cui, Y.W. Granulation of halophilic sludge inoculated with estuarine sediments for saline wastewater treatment. Sci. Total Environ. 2019, 682, 532-540. [CrossRef]

9. Ulu, F.; Kobya, M. Ammonia removal from wastewater by air stripping and recovery struvite and calcium sulphate precipitations from anesthetic gases manufacturing wastewater. J. Water Process. Eng. 2020, 38, 101641. [CrossRef]

10. Campo, R.; Sguanci, S.; Caffaz, S.; Mazzoli, L.; Ramazzotti, M.; Lubello, C.; Lotti, T. Efficient carbon, nitrogen and phosphorus removal from low C/N real domestic wastewater with aerobic granular sludge. Bioresour. Technol. 2020, 305, 122961. [CrossRef]

11. Dos Santos, P.; Daniel, L. A review: Organic matter and ammonia removal by biological activated carbon filtration for water and wastewater treatment. Int. J. Environ. Sci. Technol. 2020, 17, 591-606. [CrossRef]

12. Duesel, B.F., Jr.; Clerkin, C.; Laurent, B.N. Apparatus and Method for Treating Hydrogen Sulfide and Ammonia in Wastewater Streams. U.S. Patent 16/368,317, 3 October 2019.

13. Watsuntorn, W.; Ruangchainikom, C.; Rene, E.R.; Lens, P.N.; Chulalaksananukul, W. Comparison of sulphide and nitrate removal from synthetic wastewater by pure and mixed cultures of nitrate-reducing, sulphide-oxidizing bacteria. Bioresour. Technol. 2019, 272, 40-47. [CrossRef]

14. Mondal, M.; Biswas, J.K.; Tsang, Y.F.; Sarkar, B.; Sarkar, D.; Rai, M.; Sarkar, S.K.; Hooda, P.S. A wastewater bacterium Bacillus sp. KUJM2 acts as an agent for remediation of potentially toxic elements and promoter of plant (Lens culinaris) growth. Chemosphere 2019, 232, 439-452. [CrossRef]

15. Tong, Y.; Wang, M.; Peñuelas, J.; Liu, X.; Paerl, H.W.; Elser, J.J.; Sardans, J.; Couture, R.M.; Larssen, T.; Hu, H. Improvement in municipal wastewater treatment alters lake nitrogen to phosphorus ratios in populated regions. Proc. Natl. Acad. Sci. USA 2020, 117, 11566-11572. [CrossRef]

16. Al Momani, F.; Örmeci, B. Assessment of algae-based wastewater treatment in hot climate region: Treatment performance and kinetics. Process. Saf. Environ. Prot. 2020, 141, 140-149. [CrossRef]

17. Sonkar, M.; Kumar, V.; Dutt, D. Use of paper mill sludge and sewage sludge powder as nitrogen and phosphorus sources with bacterial consortium for the treatment of paper industry wastewater. Biocatal. Agric. Biotechnol. 2020, 30, 101843. [CrossRef]

18. Fan, F.; Xu, R.; Wang, D.; Meng, F. Application of activated sludge for odor control in wastewater treatment plants: Approaches, advances and outlooks. Water Res. 2020, 115915. [CrossRef]

19. Sookpanya, P.; Suadee, W.; Pharamat, T.; Suwannachot, S.; Ratcha, M. Kinetics of organic and inorganic degradation in biofilter using isolated bacteria from petrochemical wastewater treatment plant. Thai. Environ. Eng. J. 2020, 34, 57-65.

20. Kim, D.H.; Han, K.I.; Kwon, H.J.; Kim, M.G.; Kim, Y.G.; Choi, D.H.; Lee, K.C.; Suh, M.K.; Kim, H.S.; Lee, J.S. Comamonas flocculans sp. nov., a floc-forming bacterium isolated from livestock wastewater. Curr. Microbiol. 2020, 1-7. [CrossRef]

21. Blandin, G.; Rosselló, B.; Monsalvo, V.M.; Batlle-Vilanova, P.; Viñas, J.M.; Rogalla, F.; Comas, J. Volatile fatty acids concentration in real wastewater by forward osmosis. J. Membr. Sci. 2019, 575, 60-70. [CrossRef]

22. Ouyang, E.; Liu, Y.; Ouyang, J.; Wang, X. Effects of different wastewater characteristics and treatment techniques on the bacterial community structure in three pharmaceutical wastewater treatment systems. Environ. Technol. 2019, 40, 329-341. [CrossRef]

23. Dijkman, H.; Strous, M. Process for the Treatment of Wastewater Containing Organic Material and Ammonia. U.S. Patent 16/317,451, 25 July 2019.

24. Li, S.; Zhang, Y.; Yin, S.; Wang, X.; Liu, T.; Deng, Z. Analysis of microbial community structure and degradation of ammonia nitrogen in groundwater in cold regions. Environ. Sci. Pollut. Res. 2020, 1-11. [CrossRef] [PubMed]

25. Kalniňš, M.; Bērzinšs, A.; Gudrā, D.; Megnis, K.; Fridmanis, D.; Danilko, P.; Muter, O. Selective enrichment of heterotrophic nitrifiers Alcaligenaceae and Alcanivorax spp. from industrial wastewaters. AIMS Microbiol. 2020, 6, 32. [CrossRef] [PubMed]

26. Garrity, G.M.; Bell, J.A.; Lilburn, T. Oceanospirillalesord. nov. In Bergey's Manual ${ }^{\circledR}$ of Systematic Bacteriology; Springer: Berlin, Germany, 2005; pp. 270-323.

27. Blázquez, E.; Guisasola, A.; Gabriel, D.; Baeza, J.A. Application of bioelectrochemical systems for the treatment of wastewaters with sulfur species. In Microbial Electrochemical Technology; Elsevier: Amsterdam, The Netherlands, 2019; pp. $641-663$.

28. Kadnikov, V.; Mardanov, A.; Beletsky, A.; Antsiferov, D.; Kovalyova, A.; Karnachuk, O.; Ravin, N. Sulfur-oxidizing bacteria dominate in the water from a flooded coal mine shaft in Kuzbass. Microbiology 2019, 88, 120-123. [CrossRef] 
29. Sorokin, D.Y.; Merkel, A.; Muyzer, G. Thioalkalibacter. In Bergey's Manual of Systematics of Archaea and Bacteria; John Wiley and Sons: Hoboken, NJ, USA, 2020.

30. Tsallagov, S.I.; Sorokin, D.Y.; Tikhonova, T.V.; Popov, V.O.; Muyzer, G. Comparative genomics of Thiohalobacter thiocyanaticus HRh1T and Guyparkeria sp. SCN-R1, halophilic chemolithoautotrophic sulfur-oxidizing gammaproteobacteria capable of using thiocyanate as energy source. Front. Microbiol. 2019, 10, 898. [CrossRef]

31. Boden, R. Reclassification of Halothiobacillus hydrothermalis and Halothiobacillus halophilus to Guyparkeria gen. nov. in the Thioalkalibacteraceae fam. nov., with emended descriptions of the genus Halothiobacillus and family Halothiobacillaceae. Int. J. Syst. Evol. Microbiol. 2017, 67, 3919-3928. [CrossRef]

32. Bambauer, A.; Rainey, F.A.; Stackebrandt, E.; Winter, J. Characterization of Aquamicrobium defluvii gen. nov. sp. nov., a thiophene-2-carboxylate-metabolizing bacterium from activated sludge. Arch. Microbiol. 1998, 169, 293-302. [CrossRef]

33. Fernandez-Gonzalez, N.; Sierra-Alvarez, R.; Field, J.A.; Amils, R.; Sanz, J.L. Adaptation of granular sludge microbial communities to nitrate, sulfide, and/or p-cresol removal. Int. Microbiol. 2019, 22, 305-316. [CrossRef]

34. Hu, H.Y.; Fujie, K.; Nakagome, H.; Urano, K.; Katayama, A. Quantitative analyses of the change in microbial diversity in a bioreactor for wastewater treatment based on respiratory quinones. Water Res. 1999, 33, 3263-3270. [CrossRef]

35. Romero, F.; Sabater, S.; Font, C.; Balcázar, J.L.; Acuña, V. Desiccation events change the microbial response to gradients of wastewater effluent pollution. Water Res. 2019, 151, 371-380. [CrossRef]

36. Wang, X.; Wen, X.; Xia, Y.; Hu, M.; Zhao, F.; Ding, K. Ammonia oxidizing bacteria community dynamics in a pilot-scale wastewater treatment plant. PloS. ONE 2012, 7, e36272. [CrossRef]

37. Sharma, P.; Tripathi, S.; Chandra, R. Metagenomic analysis for profiling of microbial communities and tolerance in metal-polluted pulp and paper industry wastewater. Bioresour. Technol. 2021, 324, 124681. [CrossRef]

38. Datta, S.; Rajnish, K.N.; Samuel, M.S.; Pugazlendhi, A.; Selvarajan, E. Metagenomic applications in microbial diversity, bioremediation, pollution monitoring, enzyme and drug discovery. A review. Environ. Chem. Lett. 2020, 18, 1229-1241. [CrossRef]

39. Korea, S. KOSTAT. Population Trends and Projections of the World and Korea. 2015. Available online: http://kostat.go.kr/ portal/eng/pressReleases /8/8/index.board?bmode=read\&aSeq=347597\&pag (accessed on 8 July 2015).

40. Wang, Y.C.; Han, M.F.; Jia, T.P.; Hu, X.R.; Zhu, H.Q.; Tong, Z.; Lin, Y.T.; Wang, C.; Liu, D.Z.; Peng, Y.Z. Emissions, measurement, and control of odor in livestock farms: A review. Sci. Total Environ. 2021, 145735. [CrossRef]

41. Bolleter, W.; Bushman, C.; Tidwell, P.W. Spectrophotometric determination of ammonia as indophenol. Anal. Chem. 1961, 33, 592-594. [CrossRef]

42. Leck, C.; Baagander, L.E. Determination of reduced sulfur compounds in aqueous solutions using gas chromatography-flame photometric detection. Anal. Chem. 1988, 60, 1680-1683. [CrossRef]

43. Hibi, K.; Tsuda, T.; Takeuchi, T.; Nakanishi, T.; Ishii, D. Studies of open-tubular microcapillary liquid chromatography: III. $\beta$, $\beta^{\prime}$-oxydipropionitrile and ethylene glycol stationary phases. J. Chromatogr. A 1979, 175, 105-111. [CrossRef]

44. Wang, Y.; Qian, P.Y. Conservative fragments in bacterial 16S rRNA genes and primer design for 16S ribosomal DNA amplicons in metagenomic studies. PloS ONE 2009, 4, e7401. [CrossRef]

45. Eddy, S.R. Accelerated profile HMM searches. PLoS Comput. Biol. 2011, 7, e1002195. [CrossRef]

46. Lee, B.; Moon, T.; Yoon, S.; Weissman, T. DUDE-Seq: Fast, flexible, and robust denoising for targeted amplicon sequencing. PLoS ONE 2017, 12, e0181463. [CrossRef]

47. Edgar, R.C. Search and clustering orders of magnitude faster than BLAST. Bioinformatics 2010, 26, 2460-2461. [CrossRef]

48. Fu, L.; Niu, B.; Zhu, Z.; Wu, S.; Li, W. CD-HIT: Accelerated for clustering the next-generation sequencing data. Bioinformatics 2012, 28, 3150-3152. [CrossRef]

49. Li, W.; Godzik, A. CD-HIT: A fast program for clustering and comparing large sets of protein or nucleotide sequences. Bioinformatics 2006, 22, 1658-1659. [CrossRef]

50. Schloss, P.D.; Westcott, S.L.; Ryabin, T.; Hall, J.R.; Hartmann, M.; Hollister, E.B.; Lesniewski, R.A.; Oakley, B.B.; Parks, D.H.; Robinson, C.J. Introducing Mothur: Open-source, platform-independent, community-supported software for describing and comparing microbial communities. Appl. Environ. Microbiol. 2009, 75, 7537-7541. [CrossRef]

51. Reasoner, D.J.; Geldreich, E. A new medium for the enumeration and subculture of bacteria from potable water. Appl. Environ. Microbiol. 1985, 49, 1-7. [CrossRef]

52. Kumar, S.; Nei, M.; Dudley, J.; Tamura, K. MEGA: A biologist-centric software for evolutionary analysis of DNA and protein sequences. Brief. Bioinform. 2008, 9, 299-306. [CrossRef]

53. Kumar, S.; Stecher, G.; Tamura, K. MEGA7: Molecular evolutionary genetics analysis version 7.0 for bigger datasets. Mol. Biol. Evol. 2016, 33, 1870-1874. [CrossRef]

54. Schwarz, G. Estimating the dimension of a model. Ann. Stat. 1978, 6, 461-464. [CrossRef]

55. Felsenstein, J. Confidence limits on phylogenies: An approach using the bootstrap. Evolution 1985, 39, 783-791. [CrossRef]

56. El Naker, N.A.; Hasan, S.W.; Yousef, A.F. Impact of current density on the function and microbial community structure in electro-bioreactors. J. Hazard. Mater. 2019, 368, 877-884. [CrossRef]

57. Chen, G.; Huang, J.; Fang, Y.; Zhao, Y.; Tian, X.; Jin, Y.; Zhao, H. Microbial community succession and pollutants removal of a novel carriers enhanced duckweed treatment system for rural wastewater in Dianchi Lake basin. Bioresour. Technol. 2019, 276, 8-17. [CrossRef] 
58. Chaturvedi, S.; Khurana, S.P. Importance of actinobacteria for bioremediation. In Plant Biotechnology: Progress in Genomic Era; Springer: Berlin, Germany, 2019; pp. 277-307.

59. Zhao, Y.; Shu, X.; Tu, Q.; Yang, Y.; Liu, C.; Fu, D.; Wei, L.; Duan, C. Pollutant removal from agricultural drainage water using a novel double-layer ditch with biofilm carriers. Bioresour. Technol. 2020, 310, 123344. [CrossRef] [PubMed]

60. Liu, J.; Zhang, H.; Zhang, P.; Wu, Y.; Gou, X.; Song, Y.; Tian, Z.; Zeng, G. Two-stage anoxic/oxic combined membrane bioreactor system for landfill leachate treatment: Pollutant removal performances and microbial community. Bioresour. Technol. 2017, 243, 738-746. [CrossRef] [PubMed]

61. Feng, S.J.; Wang, Z.; Huang, T.L.; Zhang, H.; Zhang, H. Simultaneous removal of nitrate, phosphorous and cadmium using a novel multifunctional biomaterial immobilized aerobic strain Proteobacteria Cupriavidus H29. Bioresour. Technol. 2020, $307,123196$.

62. LaFrentz, S.; Abarca, E.; Mohammed, H.H.; Cuming, R.; Arias, C.R. Characterization of the normal equine conjunctival bacterial community using culture-independent methods. Vet. Ophthalmol. 2020, 23, 480-488. [CrossRef] [PubMed]

63. Rastogi, G.; Sani, R.K. Molecular techniques to assess microbial community structure, function, and dynamics in the environment. In Microbes and Microbial Technology; Springer: Berlin, Germany, 2011; pp. 29-57.

64. Suttner, B.; Johnston, E.R.; Orellana, L.H.; Rodriguez, R.L.M.; Hatt, J.K.; Carychao, D.; Carter, M.Q.; Cooley, M.B.; Konstantinidis, K.T. Metagenomics as a public health risk assessment tool in a study of natural creek sediments influenced by agricultural and livestock runoff: Potential and limitations. Appl. Environ. Microbiol. 2020, 86, e02525. [CrossRef] [PubMed]

65. Efron, B.; Halloran, E.; Holmes, S. Bootstrap confidence levels for phylogenetic trees. Proc. Natl. Acad. Sci. USA 1996, $93,13429$. [CrossRef] [PubMed]

66. Pla, L. Bootstrap confidence intervals for the Shannon biodiversity index: A simulation study. J. Agr. Biol. Envir. St. 2004, 9, 42. [CrossRef]

67. Daubin, V.; Gouy, M.; Perriere, G. A phylogenomic approach to bacterial phylogeny: Evidence of a core of genes sharing a common history. Genome Res. 2002, 12, 1080-1090. [CrossRef]

68. Sharma, P.; Pandey, A.K.; Udayan, A.; Kumar, S. Role of microbial community and metal-binding proteins in phytoremediation of heavy metals from industrial wastewater. Bioresour. Technol. 2021, 124750. [CrossRef]

69. Kannan, A.D.; Evans, P.; Parameswaran, P. Long-term microbial community dynamics in a pilot-scale gas sparged anaerobic membrane bioreactor treating municipal wastewater under seasonal variations. Bioresour. Technol. 2020, 310, 123425. [CrossRef]

70. Ferro, L.; Hu, Y.O.; Gentili, F.G.; Andersson, A.F.; Funk, C. DNA metabarcoding reveals microbial community dynamics in a microalgae-based municipal wastewater treatment open photobioreactor. Algal Res. 2020, 51, 102043. [CrossRef]

71. Ospina-Betancourth, C.; Acharya, K.; Allen, B.; Entwistle, J.; Head, I.M.; Sanabria, J.; Curtis, T.P. Enrichment of nitrogen-fixing bacteria in a nitrogen-deficient wastewater treatment system. Environ. Sci. Technol. 2020, 54, 3539-3548. [CrossRef]

72. Chen, J.; Wei, J.; Ma, C.; Yang, Z.; Li, Z.; Yang, X.; Wang, M.; Zhang, H.; Hu, J.; Zhang, C. Photosynthetic bacteria-based technology is a potential alternative to meet sustainable wastewater treatment requirement? Environ. Int. 2020, 137, 105417. [CrossRef]

73. Pan, Z.; Zhou, J.; Lin, Z.; Wang, Y.; Zhao, P.; Zhou, J.; Liu, S.; He, X. Effects of COD/TN ratio on nitrogen removal efficiency, microbial community for high saline wastewater treatment based on heterotrophic nitrification-aerobic denitrification process. Bioresour. Technol. 2020, 301, 122726. [CrossRef]

74. Bedoya, K.; Hoyos, O.; Zurek, E.; Cabarcas, F.; Alzate, J.F. Annual microbial community dynamics in a full-scale anaerobic sludge digester from a wastewater treatment plant in Colombia. Sci. Total Environ. 2020, 726, 138479. [CrossRef]

75. González-Morales, S.I.; Pacheco-Gutiérrez, N.B.; Ramírez-Rodríguez, C.A.; Brito-Bello, A.A.; Estrella-Hernández, P.; HerreraEstrella, L.; López-Arredondo, D.L. Metabolic engineering of phosphite metabolism in Synechococcus elongatus PCC 7942 as an effective measure to control biological contaminants in outdoor raceway ponds. Biotechnol. Biofuels 2020, 13, 1-19. [CrossRef]

76. Wang, X.; Chen, Z.; Shen, J.; Kang, J.; Zhang, X.; Li, J.; Zhao, X. Effect of carbon source on pollutant removal and microbial community dynamics in treatment of swine wastewater containing antibiotics by aerobic granular sludge. Chemosphere 2020, 260, 127544. [CrossRef] 